\title{
The effect of financial resource availability on entrepreneurial orientation, customer orientation and firm performance in an international context: an empirical analysis from Austria and Hungary ${ }^{*}$
}

\author{
Matthias Filser, Fabian Eggers, Sascha Kraus and Éva Málovics ${ }^{* *}$
}

This study investigates the impact of financial resource availability on entrepreneurial orientation (EO), customer orientation (CO) and on growth in small- and medium-sized enterprises (SME) in Austria and Hungary. Structural equation modeling revealed that financial resource availability is attributed to EO and, subsequently, to firm growth. However, differences prevail between the two analyzed countries. While financial resource availability fosters $\mathrm{CO}$ in Hungary, there is no effect identified with regard to financial resource availability and $\mathrm{CO}$ in Austria. Furthermore, the effect of $\mathrm{CO}$ on firm growth showed negative effects in both of the analyzed countries.

Der vorliegende Artikel untersucht den Einfluss von finanzieller Ressourcenverfügbarkeit auf unternehmerische Orientierung, Kundenorientierung und Wachstum klein- und mittelgroßer Unternehmen (KMU) in Österreich und Ungarn. Aus den Strukturgleichungsmodellen geht hervor, dass die Verfügbarkeit finanzieller Ressourcen eine unternehmerische Orientierung und damit einhergehend Unternehmenswachstum positiv beeinflusst. Ferner wurden Unterschiede zwischen den analysierten Ländern festgestellt. So begünstigt finanzielle Ressourcenverfügbarkeit eine Kundenorientierung in ungarischen Unternehmen, während dies in österreichischen Unternehmen nicht konstatiert werden konnte. Letztlich zeigen die Ergebnisse unserer Untersuchung, dass von Kundenorientierung ein negativer Einfluss auf Unternehmenswachstum ausgeht.

Keywords: Entrepreneurship, Entrepreneurial Orientation, Customer Orientation, Innovativeness, Proactiveness, Risk-taking, Responsiveness, Financial resource availability, Firm performance, Multi-country study (JEL: L26, O16, O31)

\footnotetext{
Manuscript received: 4.5.12, accepted: 10.2.13 (2 revisions)

** Matthias Filser, Project Researcher, University of Turku, Finland; Ph.D. student, Utrecht University, Netherlands. Main research interests: Entrepreneurship, strategic entrepreneurship and family business research.

Fabian Eggers, Assistant Professor of Marketing, Menlo College, USA. Main research interests: interface between marketing and entrepreneurship, entrepreneurial marketing and strategic entrepreneurship.

Sascha Kraus, Professor of Entrepreneurship, University of Liechtenstein, Professor, Utrecht University, Netherlands; Adjunct Professor, Lappeenranta University of Technology, Finland. Main research interests: entrepreneurship, strategic entrepreneurship, international entrepreneurship and family business research.

Éva Málovic, Associate Professor, University of Szeged, Hungary. Main research interests: organizational culture, human resource management and family business research.
} 


\section{Introduction}

A sustainable competitive advantage is a cornerstone of any firm's viability. After all, it generates above-average performance and growth opportunities (Porter 1985; Aaker 1989; Narver/Slater 1990). The increasing pressure on today's firms coming from globalization makes it hard to develop enduring competitive advantages and improve business performance. Effective management of these pressures is becoming increasingly important. Turbulent markets with rapidly changing and uncertain environmental variables exacerbate the challenge to make the "proper" decisions and lead the company in the "right" direction. Indeed, strategic orientations may play an important role in this decision making process. The relationship between strategic orientations and firm performance has become an extensively investigated topic in the past decades. Previous research suggests that strategic orientations such as entrepreneurial orientation (EO), market orientation (MO), and customer orientation (CO) may have a positive effect on business performance and firm growth as a result. However, research on strategic orientations has generated inconsistent results. Various researchers suggest that high levels of innovativeness (Deshpande et al. 1993; Zahra/Bogner 2000) lead to success, while others conclude that proactiveness (Miller/Friesen 1983; Lumpkin/Dess 2001 ) is the main driver for performance. Furthermore, Begley and Boyd (1987) implicate that risk-taking leads to success, although an over-exposure of risktaking is contradictory. Although there is a general understanding that these constructs are somehow related to increasing firm success, empirical studies have assumed different relationships among them, have measured them differently, and have thus obtained different results, leading to different implications for small- and medium-sized enterprises (SMEs). This is particularly the case for the relationships between EO and MO as well as between MO and CO. MO has an overlap with both EO and CO concerning the dimensions according to which they are measured (Slater/Narver 1998). While proactiveness is a dimension that is attributed to EO (Covin/Slevin 1986; Covin/Slevin 1988), CO is characterized by responsiveness (Narver et al. 2004), while both proactiveness and responsiveness are dimensions of EO. For reasons of selectivity and uniqueness, we will therefore concentrate our investigation in this paper solely on EO and CO.

Most studies investigating the effects of strategic orientations on firm performance focus on large enterprises. SMEs are largely ignored, even though they represent the "backbone" of European economies and are a major engine of economic growth (Keskin 2006; Henderson/Weiler 2010; European Commission 2012). From an economic and political perspective, the understanding of growth factors is crucial since small- and growth-oriented enterprises are a major basis of employment creation (Ackelsberg/Arlow 1985; Parker 2004; Valliere 2006). However, management research has still not found 
an overarching explanation for the growth of SMEs (Davidsson et al. 2005). Growth - at least to some extent (Garnsey 1998) - is a prerequisite to overcoming predominant liabilities of smallness or newness (see e.g., Aldrich/Auster 1986; Brüderl/Schüßler 1990) and fostering the ability to compete prosperously. So when it comes to entrepreneurship research, firm growth has turned into the most significant indicator for overall corporate success (Carton/Hofer 2006).

In order to assist SMEs with different national and cultural backgrounds in their strategic decision-making processes and consequently promote their growth, it strikes us as important to investigate the strategic orientations of EO and $\mathrm{CO}$ in different environments. We also need to examine determinants that influence the strength of EO and CO. Here, we argue that these two management orientations are impacted by the availability of financial resources.

New initiatives can be realized by the use of uncommitted resources. In other words, the consistency and nature of a firm's resource bundle(s) affect company success (Barney 1991; Chandler/Hanks 1994). Hence, through available financial resources (which are the most eclectic of all resources) firms have the ability to buy or create additional indispensable resources (Penrose 1959; Garnsey 1998). Indeed, as stated by Borch et al. (1999) and Macedo and Pinho (2006), the access to financial resources biases the strategic orientation of SMEs. Nevertheless, as far as the authors are aware, there is no empirical study that comprehensively and independently investigates the variable of "financial resources" with regard to their effect on management orientations such as CO and EO. Therefore, testing the impact of financial resource availability on EO and $\mathrm{CO}$ and, as a consequence thereof, the impact on firm performance, this paper will provide further insights into these orientations.

This research is motivated by the idea to ascertain the differences between East and West European countries. Austria and Hungary in some ways share a common history (repatriating to a dual monarchy between Austria and Hungary from 1867 to 1918), so it seems interesting to investigate possible differences with regard to the autonomous progression of these two countries (Roman 2003). By conducting a quantitative empirical investigation of SMEs located in Austria and Hungary, the aim of this study is to highlight environmental as well as provincial differences that result from the effect of financial resource availability on $\mathrm{EO}$ and $\mathrm{CO}$, and subsequently on firm performance.

\section{Austria and Hungary as countries of investigation}

\subsection{Economic perspective}

Considering a general perspective, East and West European countries differ regarding the influence of capitalism and communism in the last century (Roman 2003). With regard to the individual historical development as well as 
economic situations, enterprises in East European countries (such as Hungary) are still less developed than in West European countries (such as Austria). Indeed, the Austrian economy was growing to a larger extent in 2010 and 2011 compared to Hungary (AHK 2012; Bank Austria 2012). While both countries are almost similar regarding population numbers, there is a significant difference regarding economic wealth (see Table 1). The gross domestic product (GDP) of Austria is ten times higher than in Hungary, even though the economic power and economic growth of both countries is mainly attributed to exports (AHK 2012; Bank Austria 2012). Furthermore, the number of SMEs and employees working for SMEs is comparable. In both countries SMEs account for more than $99 \%$ of the total number of enterprises.

Table 1: Demographic and economic key figures - Austria vs. Hungary

\begin{tabular}{|c|c|c|c|}
\hline Characteristics & & Austria & Hungary \\
\hline Population & & 8.388 Mio. & 9.986 Mio. \\
\hline $\begin{array}{l}\text { GDP at current } \\
\text { prices }\end{array}$ & & 301.308 Bn. & $28,154 \mathrm{Bn}$. \\
\hline \multirow[t]{3}{*}{ Number of SMEs } & Micro enterprise $=10$ employees or less & $88.1 \%$ & $94.2 \%$ \\
\hline & $\begin{array}{l}\text { Small enterprise }=\text { Between } 10 \text { and } 50 \\
\text { employees }\end{array}$ & $10.0 \%$ & $4.8 \%$ \\
\hline & $\begin{array}{l}\text { Medium enterprise }=\text { Between } 51 \text { and } \\
250 \text { employees }\end{array}$ & $1.6 \%$ & $0.8 \%$ \\
\hline \multirow{3}{*}{$\begin{array}{l}\text { Number of } \\
\text { employees }\end{array}$} & Micro enterprise $=10$ employees or less & $25.1 \%$ & $35.1 \%$ \\
\hline & $\begin{array}{l}\text { Small enterprise }=\text { Between } 10 \text { and } 50 \\
\text { employees }\end{array}$ & $23.1 \%$ & $19.4 \%$ \\
\hline & $\begin{array}{l}\text { Medium enterprise }=\text { Between } 51 \text { and } \\
250 \text { employees }\end{array}$ & $18.9 \%$ & $16.7 \%$ \\
\hline
\end{tabular}

(Source: International Monetary Fund 2012; European Commission 2011a; 2011b)

In addition, based on key figures provided by the European Commission (2011a; 2011b) as well as the Global Entrepreneurship Research Association (2012), differences exist between Austria and Hungary regarding entrepreneurial activities, attitudes, and perspectives. In both countries entrepreneurial activities are on an average level compared to other European countries. While the startup creation rate is slightly higher in Austria, the intention to start a business is greater in Hungary. Entrepreneurial activities in Austria are nevertheless driven to a larger extent by opportunities than in Hungary. This means that Austrians regard their environment as a solid one in which to start a business, while Hungarians tend to remain skeptical about theirs (European Commission 2011a; 2011b; Kallay et al. 2008). 
In addition, public financial support is lower in Hungary, and the rate of rejected loans to SMEs is higher in Hungary compared to Austria. Likewise, venture capital investments are lower in Hungary than in Austria (European Commission 2011a; 2011b). In this regard, Acs et al. (2007) emphasize that direct foreign investments foster knowledge spillovers and might even create fertile ground for bringing in the latest technologies.

The difference between Austria and Hungary is clear when it comes to the development and introduction of innovation. While Austria is above the European average, Hungary is far below it. Austrian firms tend to develop and introduce products, processes, marketing or organizational innovations to a larger extent than Hungarian SMEs. This might however be due to the effects of government-funded research and investment in employee education and training, which is far higher in Austria (European Commission 2011a; 2011b).

\subsection{Cultural perspective}

As made clear by Hofstede's $(2010 ; 2012)$ as well as the GLOBE (Global Leadership and Organizational Behavior Effectiveness) study (Bakacsi et al. 2002; Gupta et al. 2002; Szabo et al. 2002; House et al. 2004; Shi/Wang 2011), differences between Austria and Hungary also prevail in terms of cultural matters. The results of these studies are used to make clear the cultural differences that are in a reasonable relation to strategic orientations. It needs however to be taken into consideration that the foundation of both studies differs, which might be a cause of their varying results. While Hofstede's results are predominantly based on non-managerial employee responses of one internationally operating company, the GLOBE study reflects data gathered from a survey of 17,000 managers of 951 multi-national organizations. In addition, Hofstede highlights six (it was initially four) cultural dimensions, whereas the GLOBE study attributes the results to nine cultural dimensions. Finally, based on the argument that cultural values drive practices, Hofstede takes a close look exclusively at cultural values, while in the GLOBE study cultural values and practices are measured and highlighted separately (for further reflection see Hofstede 2006 and Javidan et al. 2006). Nevertheless, the results of both investigations are considered for the purpose of elaborating cultural differences between Austria and Hungary that can be attributed to strategic orientations.

The power distance in Austria is less distinct than in Hungary, i.e. power is more decentralized in Austria. Furthermore, in Hungary employees are more controlled, and the attitude towards managers is more formal than in Austria. On the other hand, open, participative, and direct communication prevails in Austria to a larger extent.

Additionally, compared to Austria, Hungarian culture is more strongly based on an individualistic ideology as well as group and family collectivism. In Hungary 
individuals are likely to take care of themselves and their families, which is evidenced by the stronger family ties found in the Hungarian culture. In contrast, institutional collectivism is higher in Austria, meaning that shared distribution of resources, joint action, and group loyalty as a result are encouraged and rewarded to a larger extent.

While the results of Hofstede (2012) show that both countries are successoriented and driven by achievements, the GLOBE study results indicate that Hungary is less performance-oriented. Among others, performance orientation is characterized by a high value of training and development accompanied by the appreciation of efforts. Moreover, Austrian culture shows stronger assertiveness, which means that its society is marked by competition, success and progress along with the anticipation of initiatives as well as aspiration towards control.

When it comes to uncertainty avoidance as well as future/long-term orientation, the results between the Hofstede (2012) and GLOBE study vary. Whereas Hofstede identifies a high avoidance of uncertainty and future orientation in Hungary, the GLOBE study emphasizes the opposite. The results for Austria in terms of uncertainty avoidance are comparable in both studies, while they differ with regard to future orientation. Because the GLOBE study surveyed only managers, the results are regarded as more appropriate in terms of strategic orientations. And the fact is, executives are the ones making decisions in terms of the strategic orientation of a company, not the employees. Thus the Hungarian culture shows a low preference for avoiding uncertainty which is accompanied by lower calculation when taking risks, as well as a moderate resilience to change (Bakacsi et al. 2002; House et al. 2004). Contrarily, Austrian society is characterized by taking moderated and calculated risks only. Decisions in Austria are made carefully on the basis of and reflection upon available information.

Finally, differences prevail when it comes to each culture's time and/or future orientation. The Austrian culture is marked by a stronger long-term orientation than the Hungarian culture. While Austrian society aims for long-term success, Hungarian society instead prefers gratification as early as possible. As a result of this kind of short-term orientation, Hungarian organizations tend to be inflexible and slow to adapt, whereas a long-term orientation such as that found in Austria tends to facilitate flexibility and rapid adaptation to changes.

\section{Entrepreneurial and customer orientation}

\subsection{Entrepreneurial orientation}

Entrepreneurship research has continuously received growing interest by scholars over the past decades (Covin et al. 2006). Nevertheless, there is still no universally valid definition of the term itself (Landström 2009). Individual opportunistic activity that creates value by risky actions which are intensely 
related to innovation is basically premised on the concept of entrepreneurship (Sexton/Kasarda 1992). Therefore, as entrepreneurship has its foundation in the entrepreneurial venture's orientation, the aim is to identify not-yet-recognized and/or unexplored market opportunities and exploit them by using a set of resources (Davidsson et al. 2002; Hitt et al. 2002). EO stems from the strategy literature through which strategy creation processes and management styles with "entrepreneurial" propensities are explained (Becherer/Maurer 1997; Lumpkin/ Dess 2001; Kraus et al. 2012).

Entrepreneurship and/or EO are considered to be drivers of company growth. As shown by numerous studies investigating the effect of EO on firm performance, firm success (mainly from a long-term perspective) is related to the construct of EO (e.g., Lumpkin/Dess 1996; Wiklund 1999; Shepherd/Wiklund 2005; Harms et al. 2010). Based on the definition of an entrepreneurially oriented business as "...one that engages in product-market innovation, undertakes somewhat risky ventures, and is first to come up with proactive innovations, beating competitors to the punch", Miller (1983, p. 771) constituted one of the first operationalizations of the EO concept. Subsequently, Miller's three EO dimensions of proactiveness, innovativeness, and risk-taking have been converted into measurable scales by Covin and Slevin (1986; 1988). The combination of these three dimensions has been approved by scholars as constituting EO (Wiklund 1999). The three-dimensional model by Miller (1983) has accordingly been applied by various investigations (e.g., Covin/Slevin 1989; Zahra/Garvis 2000; Wiklund/Shepherd 2005; Kraus 2011).

Innovations and/or innovativeness were first emphasized by Schumpeter (1942) in terms of the entrepreneurial process. Therefore, the realization of innovative ideas as well as the process of "creative destruction" are considered to be entrepreneurial behavior. Creative destruction refers to a process that prevails when wealth is created by the introduction of new products or services that disrupt the contemporary market and induce a shift of resources. On the contrary, new enterprises are created by the utilization of existing companies' resources. Nevertheless, the process of creative destruction is predominantly based on entrepreneurs' attitudes. As a result, innovation is regarded as a vital success factor within the concept of EO (Lumpkin/Dess 1996). As stated by Lumpkin and Dess (1996), “innovativeness reflects a firm's tendency to engage in and support new ideas, novelty, experimentation, and creative processes that may result in new products, services, or technological processes" (p. 142).

Risk-taking, the second EO dimension, was first mentioned by Knight (1921) as a major characteristic for entrepreneurs, especially since entrepreneurial behavior is often attributed to uncertainty (Lumpkin/ Dess 1996; Low/ MacMillan 1988). Nevertheless, compared to a company employee, an entrepreneur usually has a greater willingness to take risks, which in consequence might lead to higher rewards (Brockhaus 1980). 
The investment of substantial resources into projects with a high chance of inefficacy is associated with entrepreneurial behavior. Accordingly, it is essential for entrepreneurs to have the ability to assess the right actions and directions for their enterprises to help them overcome and/or fend off uncertainty (Ricketts 2006). However, the focus here is on calculated risk-taking rather than major and unregulated risky actions (Morris et al. 2008).

Proactiveness, the third EO dimension, refers to the projection and identification of future problems, needs, and changes. Here the focus lies on the initiative to explore, evaluate and exploit new opportunities by creating new products or services, or contributing to emerging markets (Entrialgo et al. 2000). The core aspect is the initiative that is taken with regard to the entrepreneurial process. Competitive advantages are created by the anticipation of upcoming requirements and needs (Lumpkin/ Dess 1996), or even by forming the environment in a new way. Enterprises are without question able to affect their own surroundings by actively observing environmental demands (Buss 1987). According to Miller (1983), a proactive business is one that "[...] is first to come up with 'proactive' innovations [...]" (p. 771). Therefore proactiveness embraces the propensity to introduce new products or services as a first mover to the market. Furthermore, proactive companies are often the initiators of things to which competitors subsequently respond. Proactive companies can thus be regarded as pioneers with regard to a specific product or service. In conclusion, proactiveness is a central dimension of EO as the first anticipator of new needs and creating new products or services, or contributing to emerging markets. These aspects are all seen as critical to entrepreneurship.

\subsection{Customer orientation}

$\mathrm{CO}$ refers to the identification of customer needs that is accompanied by the development of products and services (Deshpande et al. 1993; Slater/Narver 1998; Narver et al. 2004). The focus of customer-oriented businesses is on the reaction to certain needs that are expressed by customers as well as meeting certain desires through the creation of products and services (Narver et al. 2004).

Contrary to EO, CO usually emphasizes a short-term perspective. Therefore, as customer-oriented businesses solely focus on the satisfaction of expressed customer needs, no supplementary value is added in terms of potential opportunities that might foster customer dependence and loyalty as a result (Narver et al. 2004). Hamel and Prahalad (1994) refer to this orientation as the "tyranny of the served market", because the world is exclusively observed from the customers' point of view. As opposed to the EO dimensions of proactiveness and innovativeness, which reflect long-term growth promoters, responsiveness aims to realize short-term results. Thus, the long-term growth effect of $\mathrm{CO}$ by itself is marginal. This is predominantly the case in dynamic market environments, in which a concentration solely on $\mathrm{CO}$ is in fact a dangerous 
strategy and increases the potential to fail (Christensen/Bower 1996; Christensen 1997). In stable environments, CO might however be a useful strategy. According to Slater and Narver (1998), it needs to be considered that "...being customer-led in a dynamic environment will rarely lead to a position of competitive advantage since it provides insufficient stimulus for the significant innovation that discontinuous change requires" (p. 1005). Accordingly, CO might promote a firm's performance because the customer is the center of focus and is served in a superior fashion. However, firm growth is critical since CO might in fact foster stagnation when only what customers are able to articulate is reacted to.

Given the aforementioned remarks, the two constructs of EO and $\mathrm{CO}$ can be broken down into their underlying dimensions (Figure 1).

Figure 1: EO and CO dimensions

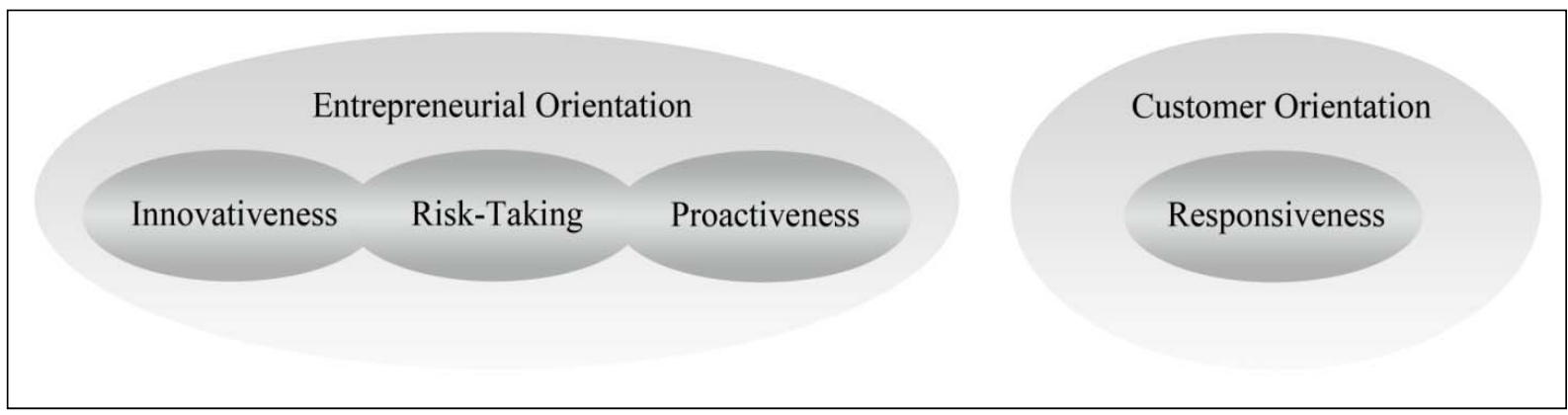

From a general perspective, and as shown in the chapters above, research provides varying results when considering the effects of $\mathrm{EO}$ and $\mathrm{CO}$ on growth. This leads to the formulation of our first two hypotheses, which are assumed as valid for both investigated countries:

H1: The more entrepreneurially oriented a firm is, the more it will grow.

H2: The more customer-oriented a firm is, the less it will grow.

\subsection{Financial resources as antecedents of $\mathrm{EO}$ and $\mathrm{CO}$}

As emphasized by Matsuno et al. (2005), potential antecedents also need to be considered when it comes to the examination of $\mathrm{EO}$ and $\mathrm{CO}$ performance impact. In this context, we argue that a firm's EO and CO behavior is affected by the availability of financial resources.

According to Delmar et al. (2003) as well as Sciascia et al. (2006), EO strategies are promoted by financial resources. Hence, $R \& D$ activities and the level of potential innovations are reduced when a business is short on funds. When this is the case, the level of risk-taking declines, as risky projects are basically undertaken only when access to capital is at a higher level. Proactiveness is also affected by available financial resources, which are gained from products that 
currently come to maturity and provide capital to generate and market new products. Lower levels of financial resources generally complicate reinvestments into new developments (Wiklund/Shepherd 2005; Katila/Shane 2005). Contrarily, the fewer financial resources that are available, the more a firm needs to focus on short-term returns that ensure its survival (Garnsey 1998; Garnsey/Heffernan 2005). Businesses gain instant revenues via predominantly CO behavior (Bhidé 2000). Consequently, CO strategies are fostered where fewer financial resources are accessible (Macedo/Pinho 2006). Ultimately, despite the indirect influences on firm performance, several authors have highlighted the direct link between financial resources and success. Here, the growth potentials of businesses are promoted by the amount of available financial resources (Levratto 1996; Wiklund 1999; Wiklund/Shepherd 2005; Eisenmann 2006). This leads to the following hypotheses:

H3: The more financial resources available, the more EO a firm will behave.

H4: The fewer financial resources available, the more CO a firm will behave.

H5: The more financial resources available, the more a firm will grow.

A theoretical perspective provides no reason to assume a country-of-origin effect regarding the hypotheses.

\section{Empirical study}

\subsection{Measures and variables}

The literature has seen an ongoing debate on the multidimensionality and the operationalization of EO and CO. Most authors use the EO scales by Miller (1983) and Covin and Slevin (1989) which build upon Miller's (1983) original conceptualization of EO as an organizational-level phenomenon, suggesting that EO involves the simultaneous implementation of innovative, proactive and risky firm behaviors. However, these scales were developed to assess the level of EO among a wide selection of firms, independent of their size or focus. Questions like: "How many new lines of products has your firm marketed in the past five years?" are however less suitable for use within the context of SMEs. In our study, we therefore used the EO and CO scales developed for SMEs by Eggers et al. (2013), which are based on the scales above, but adapted to the specific kind of firms, consisting of five items for innovativeness, four for risk-taking, and five for proactiveness (EO), as well as five for responsiveness (CO).

In addition, financial resource availability (Atuahene-Gima et al. 2005) was measured with three items, and firm growth (Chen et al. 2007) with two items (growth being the most-used success indicator in entrepreneurship research; Carton/Hofer 2006; Davidsson et al. 2009), based on existing scales. 
All scale items were scored using a 5-point Likert-type scale with response options from 1 ("do not agree") to 5 ("strongly agree"), with higher scores indicating higher levels of the construct in question. One item was reverse scored. Our questionnaire contained a total of 37 questions, and since our survey was geared towards German- and Hungarian-speaking business executives (Brislin 1980), was subjected to double-blind translation to improve the validity and reliability of the measuring instruments. Survey translators were all academics with backgrounds in entrepreneurship research. First the original scale items were translated from English into German and Hungarian, and subsequently back-translated by other independent translators. If the meaning after the retranslation differed, the problem was discussed by both translators and a new wording for the question was developed. Two additional translators checked the revision of the questions. Finally, all translations were once again compared with the original questions before conducting the survey to identify and correct errors that may have arisen due to interpretation differences (Brislin 1980).

\subsection{Sample}

The final questionnaire was translated into an online survey (Qualtrics, Inc.) and emailed to 10,000 randomly selected SMEs in Austria and Hungary each in the spring of 2011. Responses from 660 companies in Austria and 456 in Hungary were successfully obtained to conduct the study. The overall response rate was $5.58 \%$.

Table 2 summarizes the main characteristics of the firms surveyed. Our dataset is comprised of enterprises with an average of 7.32 employees in Austria and 5.98 employees in Hungary. Our sample is furthermore balanced by sector, with a slight majority of firms belonging to the service sector in Austria and to the industry sector in Hungary. 
Table 2: Sample characteristics

\begin{tabular}{|l|l|l|l|}
\hline Characteristic & & Austria & Hungary \\
\hline $\begin{array}{l}\text { Size of firms } \\
\text { (employees) }\end{array}$ & Micro enterprise = 10 employees or less & $68.8 \%$ & $52.2 \%$ \\
\cline { 2 - 4 } & $\begin{array}{l}\text { Small enterprise = Between } 10 \text { and } 50 \\
\text { employees }\end{array}$ & $19.3 \%$ & $36 \%$ \\
\cline { 2 - 4 } & $\begin{array}{l}\text { Medium enterprise = Between 51 and 250 } \\
\text { employees }\end{array}$ & $11.9 \%$ & $11.8 \%$ \\
\hline \multirow{5}{*}{ Sector } & Agriculture & $0.6 \%$ & $10.3 \%$ \\
\cline { 2 - 4 } & Manufacturing Industry & $13.0 \%$ & $8.8 \%$ \\
\cline { 2 - 4 } & Building Industry & $7.4 \%$ & $13.2 \%$ \\
\cline { 2 - 4 } & Trade & $9.3 \%$ & $23.9 \%$ \\
\cline { 2 - 4 } & Transport Industry & $3.5 \%$ & $7.2 \%$ \\
\cline { 2 - 4 } & Financial \& insurance services & $3.1 \%$ & $8.3 \%$ \\
\cline { 2 - 4 } & Freelancing, scientific \& technical services & $26.5 \%$ & $5.7 \%$ \\
\cline { 2 - 4 } & Food service industry/gastronomy & $13.0 \%$ & - \\
\cline { 2 - 4 } & Information and communication services & $17.7 \%$ & $10.7 \%$ \\
\cline { 2 - 4 } & Education & $2.5 \%$ & $9.6 \%$ \\
\cline { 2 - 4 } & Others & & $2 \%$ \\
\hline
\end{tabular}

\section{Analysis and results}

To determine the results, we used SPSS and AMOS (v. 19.0) to construct structural equation models (SEM) for both countries analyzed. The analysis was carried out in a two-stage process. First, all reflective measures were analyzed in light of reliability and validity. The results suggest that the standardized loadings are significant and show adequate values for all items observed. Detailed results can be found in Table 3 below. We conclude that the underlying constructs are valid.

The model fit for both countries analyzed was determined by both absolute and incremental fit indices. The global fit statistics (Chi-Square $\chi^{2}=485.7$; Normed Chi-Square $\left(\chi^{2} / \mathrm{df}\right)=4.048$; RMSEA $\left.=0.052 ; \mathrm{CFI}=0.918\right)$ are acceptable and show a good fit. The absolute fit index $\chi^{2} / \mathrm{df}$ (4.048) shows a ratio of approximately $4: 1$, which is associated with a good descriptive fit considering the sample size (Kline 1998; Hair et al. 2010). For the root mean square error of approximation (RMSEA), measures between 0.03 and 0.08 usually reflect a good fit to the population. Finally, a CFI value greater than 0.90 is usually associated with a good model fit (Browne/Cudeck 1993; Hair et al. 2010). Thus 
the dimensionality and convergent validity of the constructs in the model are confirmed (Anderson/Gerbing 1988; Fornell/Larcker 1981; Hair et al. 2010).

The outcomes of the SEM for both analyzed countries are illustrated, described, and compared in the following.

The SEM for Austria (Figure 2) shows that financial resource availability has a highly significant influence on growth. Furthermore, financial resource availability strongly affects EO and growth in Austrian SMEs as a result. 18\% of the variance of EO is explained by financial resource availability with a standardized regression weight of 0.42 . Consequently, the more financial resources an SME has, the more EO it reported and vice versa. However, on the basis of a standardized regression weight of -0.09 , financial resource availability negatively influences $\mathrm{CO}$ and subsequently the negative impact of $\mathrm{CO}$ on growth. This means that the more financial resources an SME has, the less CO it shows and vice versa. Finally, $45 \%$ firm growth is explained by the three variables of $\mathrm{EO}, \mathrm{CO}$ and financial resource availability, with standardized regression weights varying between 0.42 and -0.09 (all significant).

Figure 2: Structural equation model Austria

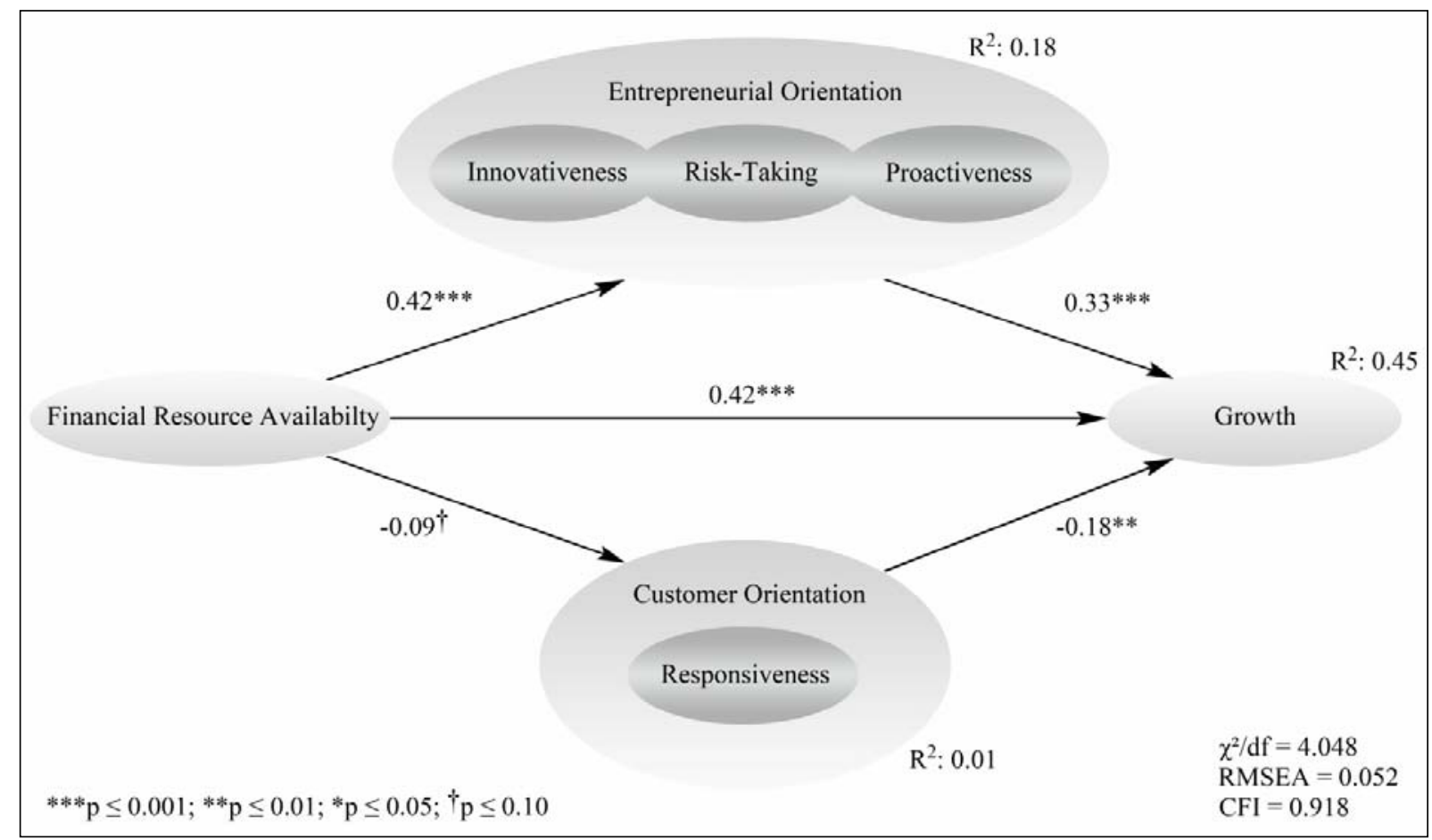

The results for Hungary (Figure 3 ) show that financial resource availability is positively linked to firm growth. Moreover, financial resource availability fosters EO and growth within a firm as a result. $46 \%$ of the variance of EO is explained by financial resource availability with a standardized regression weight of 0.68 . Consequently, similar to the results in Austria, the more financial resources an SME has, the more EO it shows and vice versa. 
Surprisingly, financial resource availability has a positive impact on $\mathrm{CO}$, while $\mathrm{CO}$ shows a negative effect on firm growth. In consequence, the more financial resources an SME has, the more $\mathrm{CO}$ it behaves and vice versa. Finally, $63 \%$ of the variance of firm growth is explained by the three variables of EO, $\mathrm{CO}$, and financial resource availability with standardized regression weights varying between 0.58 and -0.19 (all significant).

Figure 3: Structural equation model Hungary

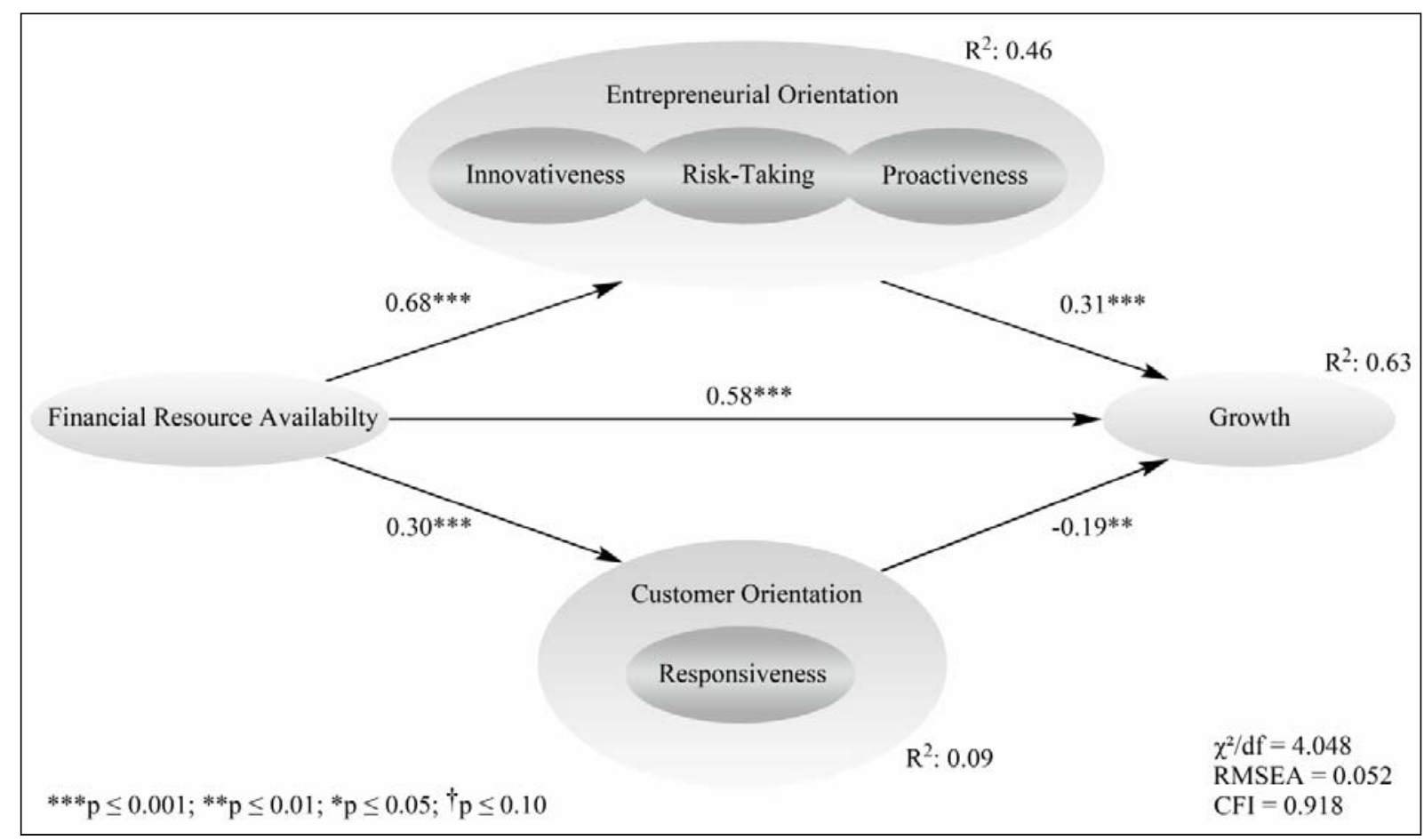

With regard to the comparison of both countries, differences prevail considering the effect of financial resource availability on CO. However, the overall result shows that, in general, growth is attributed to financial resource availability. Furthermore, the findings make clear that financial resource availability promotes EO, and a positive effect on growth is observed regardless of the country. Nevertheless, the extent to which the variance of EO is explained by financial resource availability is larger in Hungary than in Austria. The model shows a greater standardized regression weight of EO for Hungarian firms. In addition, the Hungarian model illustrates stronger effects of financial resource availability on EO as well as a stronger direct effect of financial resource availability on growth. Overall, the Hungarian model explains a larger share of SME growth (0.63) than the Austrian model (0.45). Finally, based on the critical ratios, statistically significant differences prevail between the two countries with regard to the effect of $\mathrm{EO}$ and $\mathrm{CO}$ on growth as well as financial resource availability on EO. Detailed results can be found in Table 3. 
Table 3: SEM results

\begin{tabular}{|l|l|l|l|}
\hline & Austria & Hungary & \\
\hline EO & 0.18 & 0.46 & \\
\hline CO & 0.01 & 0.09 & \\
\hline Firm growth & 0.45 & 0.63 & \\
\hline Path coefficients & \multicolumn{2}{|c|}{ Standardized Estimates } & \\
\hline EO -> Innovativeness & $0.97^{* * *}$ & $0.91^{* * *}$ & \\
\hline EO -> Risk-taking & $0.50^{* * *}$ & $0.67^{* * *}$ & \\
\hline EO -> Proactiveness & $0.72^{* * *}$ & $0.70^{* * *}$ & \\
\hline $\begin{array}{l}\text { CO -> Responsiveness } * \\
\text { CO }=\text { Responsiveness }\end{array}$ & $0.73^{* * *}$ & $0.63^{* * *}$ & \\
\hline $\begin{array}{l}* \text { (accumulated variance and significance of the scale items on } \\
\text { responsiveness })\end{array}$ & \multicolumn{4}{|l|}{ Standardized Estimates } & C.R. \\
\hline Relationship Variables & $0.33^{* * *}$ & $0.31^{* * *}$ & 4.581 \\
\hline EO -> growth & $-0.18^{* *}$ & $-0.19^{* * *}$ & 3.457 \\
\hline CO -> growth & $0.42^{* * *}$ & $0.68^{* * *}$ & 2.472 \\
\hline Financial resource availability -> EO & $-0.09^{\dagger}$ & $0.30^{* * *}$ & -0.892 \\
\hline Financial resource availability -> CO & $0.42^{* * *}$ & $0.58^{* * *}$ & 0.186 \\
\hline $\begin{array}{l}\text { Financial resource availability -> } \\
\text { growth }\end{array}$ & \multicolumn{4}{|l}{} \\
\hline
\end{tabular}

$* * * \mathrm{p} \leq 0.001 ; * * \mathrm{p} \leq 0.01 ;{ }^{*} \mathrm{p} \leq 0.05 ;{ }^{\dagger} \mathrm{p} \leq 0.10$

Model fit statistics: Chi-Square $=485.7 ; \chi^{2} / \mathrm{df}=4.048 ; \mathrm{RMSEA}=0.052 ; \mathrm{CFI}=0.0918$

All items scored from 1 to 5 (Austria $n=660$; Hungary $n=456$ )

\section{Discussion and limitations}

The primary contribution of this study to the literature on strategic orientations is that financial resource availability promotes EO and SME growth as a result $(H 1, H 3)$. Furthermore, financial resource availability in general has a significantly positive effect on firm growth (H5). Our study shows that the more financial resources an SME possesses, the more likely it is to be "entrepreneurially oriented" $(H 3)$, and the more it grows as a result $(H 1, H 5)$. Therefore, any firm that intends to grow will require EO. The results for Austria nevertheless show that the fewer financial resources that are available, the more likely an SME is to be "customer-oriented" ( $\mathrm{H} 4)$, only responding to explicitlymentioned customer needs. In this case, the firm does not entrepreneurially "shape its market" on its own and is therefore limited in its growth $(H 2)$. 
In the Hungarian dataset, the relationship between financial resource availability and $\mathrm{CO}$ is reversed (H4). Contrary to the results in Austria, the higher Hungarian firms score on $\mathrm{CO}$, the less they grow (H2). The hypothesized relationships and the results of our analyses are illustrated in Table 4.

Table 4: Hypotheses results

\begin{tabular}{|l|l|l|l|l|}
\hline H. & Relationship & \multicolumn{2}{|l|}{ Conclusion } & Comments \\
\hline H1 & EO -> growth & Confirmed & Confirmed & $\begin{array}{l}\text { The relations are } \\
\text { significant in the proposed } \\
\text { direction. }\end{array}$ \\
\hline H2 & CO -> growth & Confirmed & Confirmed & $\begin{array}{l}\text { The relations are } \\
\text { significant in the proposed } \\
\text { direction. }\end{array}$ \\
\hline H3 & $\begin{array}{l}\text { Financial resource } \\
\text { availability -> EO }\end{array}$ & Confirmed & Confirmed & $\begin{array}{l}\text { The relations are } \\
\text { significant in the proposed } \\
\text { direction. }\end{array}$ \\
\hline H4 & $\begin{array}{l}\text { Financial resource } \\
\text { availability -> CO }\end{array}$ & Confirmed & Not \\
confirmed & $\begin{array}{l}\text { The relation is slightly } \\
\text { significant in the case of } \\
\text { Austria, while the results } \\
\text { show a significant relation } \\
\text { in the reverse direction for } \\
\text { Hungary. }\end{array}$ \\
\hline H5 & $\begin{array}{l}\text { Financial resource } \\
\text { availability -> } \\
\text { growth }\end{array}$ & Confirmed & Confirmed & $\begin{array}{l}\text { The relations are } \\
\text { significant in the proposed } \\
\text { direction. }\end{array}$ \\
\hline
\end{tabular}

The question arises why the variables in the model of Hungary (63\%) explain more of the variation of growth than in the Austrian model (45\%). There's also the question why financial resource availability is positively linked to $\mathrm{CO}$ in Hungary $\left(0.30^{* * *}\right)$, and negatively in Austria (accompanied by a slightly significant effect $\left(0.09^{\dagger}\right)$ ).

Considering a general perspective, East and West European countries differ in some ways regarding the influence of capitalism and communism in the last century (Roman 2003). As there may be still a slight influence concerning their historical background, SMEs in Hungary (East Europe) might be in a transition phase, developing at a faster pace than the further-developed countries of the West (such as Austria). At the same time, Hungarian firms still act conservatively by focusing on both $\mathrm{EO}$ and $\mathrm{CO}$ regardless of the effect shown in our paper of $\mathrm{CO}$ on growth. Older generations of business owners in particular 
might rely on traditional orientations, have difficulty changing their perspective, and thereby fully adapt to an EO. This might be due to the power distance in Hungary, where employees are more controlled and the attitude towards managers is more formal than in Austria (Hofstede 2012). Freedom regarding individual initiatives is in some ways limited as the business orientation within Hungarian firms is mainly based on the perception and attitude of the business owner. Likewise, the development of an entrepreneurial attitude and the awareness and ability of employees regarding individual initiatives may be held in lower esteem in Hungary than in Austria due to lower investments in education and training of employees. In this regard, another explanatory factor might be how the facilitation of an entrepreneurial attitude via education is rated lower in Hungary (European Commission 2011a; 2011b).

Additionally, due to a higher individualistic ideology accompanied by stronger family ties in Hungary (Hofstede 2012), business decisions might be affected by older generations to a larger extent than in Austrian enterprises. However, as Hungarian firms are pessimistic considering the current economic situation as well as the forecast for future development (Kallay et al. 2008; AHK 2012; European Commission 2011a; 2011b), they might tend to avoid a "pure" EO. Furthermore, the concentration on both $\mathrm{EO}$ and $\mathrm{CO}$ might be related to the fact that opportunities in the respective environment are estimated to be more limited in Hungary than in Austria. Likewise, the reliance on $\mathrm{CO}$ along with EO, and a slightly existing risk aversion as a result, might be affiliated with the unpredictability of the economic policy; statistics indicate that enterprises in Hungary reveal the highest dissatisfaction concerning this matter (Kallay et al. 2008; AHK 2012; European Commission 2011a; 2011b).

Moreover, since the majority of businesses in Hungary see the economic situation as difficult, which is accompanied by poor estimations regarding revenues and profits, Hungarian firms might to some extent be confronted with a lack of financial resources (AHK 2012). The lack of financial resources in Hungary can be equally exacerbated by the higher rate of loans refused to SMEs, lower public financial support, as well as the lower investment rate of venture capitalists in Hungarian startups compared to Austria (European Commission 2011a; 2011b). As a consequence, Hungarian business founders predominantly rely on their own resources (Mako/Kuczi 2003).

Additionally, the reason why Hungarian firms concentrate on a combination of both EO and CO might be explained by the fact that Hungarians tend to be less adaptive, and have a higher fear of failure than Austrians (Bakacsi et al. 2002; Global Entrepreneurship Research Association 2012; House et al. 2004). Likewise, Hungarian firms tend to develop and introduce fewer innovations (European Commission 2011a; 2011b), which reflects a "non-pure" EO. Nevertheless, a concentration solely on EO would require the adaption to a more entrepreneurial as well as long-term attitude and thereby more innovative 
outcomes. This indeed further explains why firms in Hungary see a combination of $\mathrm{EO}$ and $\mathrm{CO}$ as promising, since $\mathrm{CO}$ in some ways reflects a short-term orientation.

Lastly, the economic growth of Hungary during the past years was mainly based on exports to European countries (AHK 2012; European Commission 2011b). With this being the case, it might be helpful to put less emphasis on $\mathrm{CO}$ to promote global competitiveness. Since the Austrian economy was growing to a larger extent in 2010 and 2011 compared to Hungary (AHK 2012; Bank Austria 2012), from a certain perspective, this supports the hypothesis that a clear focus on EO is a promising orientation towards growing and fostering sustainable growth.

When it comes to the limitations of our study, we first mention the fact that the samples for Austria and Hungary slightly differ concerning the related sectors as well as the number of micro, small, and medium enterprises. Gathering entirely consistent samples nevertheless remains elusive. Additionally, it would have been interesting to investigate our model by placing firm age alongside firm size to elaborate on the potential differences between young and established enterprises. Our data sample however does not contain information about the age of the investigated firms and therefore does not allow such an analysis. Important to also remember is that we used an online-based questionnaire to gather our dataset. Even though electronic data collection methods are becoming widespread, this method might have biased our findings concerning (among other things) access and sampling issues as well as response tendencies (see e.g., Duffy et al. 2005; Sax et al. 2003; Wright 2005).

\section{Conclusion}

In terms of practical implications, this study's results emphasize that sustainable firm growth is solely achievable with an EO. Nevertheless, CO might equally provide value to businesses in some way. It should be kept in mind that not focusing on EO does not necessarily mean that a firm is $\mathrm{CO}$ by default. However, if it is difficult for an SME to implement an EO, the recommendation is in fact to focus on $\mathrm{CO}$ regardless of the effect, especially when considering a long-term or short-term duration. An influential strategy to be kept in mind is a focus on customers and sufficiently responding to their needs.

In terms of theoretical implications, we suggest exploring the relationship between EO and CO in greater detail. As shown in our study, breaking each orientation down to its underlying dimensions provides a clearer picture of the impact of every dimension on the respective orientation(s).

The findings shown here provide a number of interesting results for future research in this area. This study is based on a cross-sectional database. A longitudinal study could without question be of value to investigate this area in 
greater detail and help verify our results further. Additionally, it would be interesting to examine how SMEs could overcome limited financial resource availability to foster EO from a long-term perspective. Although we do not argue that $\mathrm{CO}$ is negatively linked to growth in general, from a long-term perspective, fostering EO is inevitable for those wishing to remain successful in the market. Moreover, we suggest that future studies should further investigate the interplay between strategic orientations by considering additional and/or various antecedents, moderators, mediators, and performance outcomes.

\section{Literature}

Aaker, D.A. (1989): Managing Assets and Skills: The Key to Sustainable Competitive. Advantage, in: California Management Review, 31, 2, 91-106.

Ackelsberg, R./Arlow, P. (1985): Small businesses do plan and it pays off, in: Long Range Planning, 18, 5, 61-67.

Acs, Z.J./O'Gorman, C./Szerb, L./Terjesen, S. (2007): Could the Irish Miracle be Repeated in Hungary?, in: Small Business Economics, 28, 2-3, 123-142.

AHK (2012): Konjunkturbericht Ungarn 2012 (Report on the Economy Hungary 2012). Hungary: AHK - Deutsch-Ungarische Industrie und Handelskammer (GermanHungarian Chamber of Commerce).

Aldrich, H./Auster, E. (1986): Even dwarfs started small: Liabilities of size and age and their strategic implication, in: Research in Organizational Behavior, 8, 65-198.

Anderson, J.C./Gerbing, D.W. (1988): Structural Equation Modeling in Practice: A Review and Recommended Two-Step Approach, in: Psychological Bulletin, 103, 3, 411-423.

Atuahene-Gima, K./Slater, S.F./Olson, E.M. (2005): The contingent value of responsive and proactive market orientations for new product program performance, in: Journal of Product Innovation Management, 22, 6, 464-482.

Bakacsi, G./Takács, S./Karácsonyi, A./Imrek, V. (2002): Eastern european cluster: tradition and transition, in: Journal of World Business, 37, 1, 69-80.

Bank Austria (ed.) (2012): Österreich Konjunktur. April 2012, Austria: Bank Austria Economics \& Market Analysis Austria.

Barney, J.B. (1991): Firm resources and sustained competitive advantage, in: Journal of Management, 17, 1, 99-120.

Becherer, R./Maurer, J. (1997): The Moderating Effect of Environmental Variables on the Entrepreneurial and Marketing Orientation of Entrepreneur-led Firms, in: Entrepreneurship Theory and Practice, 22, 1, 47-58.

Begley, T.M./Boyd, D.P. (1987): Psychological Characteristics Associated with Performance in Entrepreneurial Firms and Small Businesses, in: Journal of Business Venturing, 2, 1, 79-93.

Bhidé, A.V. (2000): The Origin and Evolution of New Businesses. Oxford: Oxford University Press. 
Borch, O.J./Huse, M./Senneseth, K. (1999): Resource configuration, competitive strategies, and corporate entrepreneurship: an empirical examination of small firms, in: Entrepreneurship Theory and Practice, 24, 1, 49-70.

Brislin, R.W. (1980): Translation and content analysis of oral and written materials, in: Triandis, H.C./Berry, J.W. (eds.): Handbook of cross-cultural psychology, Boston: Allyn and Bacon, 389-444.

Brockhaus, R.H. (1980): Risk-taking propensity of entrepreneurs, in: Academy of Management Journal, 23, 3, 509-520.

Brüderl, J./Schüßler, R. (1990): Organizational Mortality: The Liabilities of Newness and Adolescence, in: Administrative Science Quarterly, 35, 3, 530 - 547.

Buss, D.M. (1987): Selection, evocation, and manipulation, in: Journal of Personality and Social Psychology, 53, 6, 1214-1221.

Carton, R.B./Hofer, C.W. (2006): Measuring Organizational Performance - Metrics for Entrepreneurship and Strategic Management Research. Cheltenham: Edward Elgar.

Chandler, G.N./Hanks, S.H. (1994): Market Attractiveness, Resource-Based Capabilities, Venture Strategies and Venture Performance, in: Journal of Business Venturing, 9, 4, 331-349.

Chen, C.-N./Tzeng, L.-C./Ou, W.-M./Chang, K.-T. (2007): The Relationship among Social Capital, Entrepreneurial Orientation, Organizational Resources and Entrepreneurial Performance for New Ventures in: Contemporary Management Research, 3, 3, 213 232.

Christensen, C.M. (1997): The Innovator's Dilemma. Boston, MA: Harvard Business School Press.

Christensen, C.M./Bower, J.L. (1996): Customer power, strategic investment, and the failure of leading firms, in: Strategic Management Journal, 17, 3, 197-218.

Commission, E. (2012): Business economy - Size class analysis. http://epp.eurostat.ec.europa.eu/statistics_explained/index.php/Business_economy__size_class_analysis (accessed April 2012).

Covin, J.G./Green, K.M./Slevin, D.P. (2006): Strategic process effects on the entrepreneurial orientation-sales growth rate relationship, in: Entrepreneurship Theory and Practice, $30,1,57-81$.

Covin, J.G./Slevin, D.P. (1986): The development and testing of an organization-level entrepreneurship scale, in: Ronstadt, R./Hornaday, J.A./Vesper, K.H. (eds.): Frontiers of Entrepreneurship Research 1986, Wellesly, MA: Babson College, 628-639.

Covin, J.G./Slevin, D.P. (1988): The influence of organization structure on the utility of an entrepreneurial top management style, in: Journal of Management Studies, 25, 3, 217 234.

Covin, J.G./Slevin, D.P. (1989): Strategic Management of Small Firms in Hostile and Benign Environments, in: Strategic Management Journal, 10, 1, 75-87.

Davidsson, P./Achtenhagen, L./Naldi, L. (2005): Research on small firm growth: A review, in: Proceedings of the European Institute of Small Business, 1-28. 
Davidsson, P./Delmar, F./Wiklund, J. (2002): Entrepreneurship as Growth: Growth as Entrepreneurship, in: Hitt, M.A./Ireland, R.D./Camp, S.M./Sexton, D.L. (eds.): Strategic entrepreneurship: Creating a new mindset, Oxford: Blackwell, 328-340.

Davidsson, P./Steffens, P./Fitzsimmons, J. (2009): Growing profitable or growing from profits: Putting the horse in front of the cart?, in: Journal of Business Venturing, 24, 4, 388-406.

Delmar, F./Davidsson, P./Gartner, W.B. (2003): Arriving at the high-growth firm, in: Journal of Business Venturing, 18, 2, 189-216.

Deshpande, R./Farley, J.U./Webster Jr., F.E. (1993): Corporate culture, customer orientation, and innovativeness in Japanese firms - a quadrad analysis, in: Journal of Marketing, $57,1,23-37$.

Duffy, B./Smith, K./Terhanian, G./Bremer, J. (2005): Comparing data from online and faceto-face surveys, in: International Journal of Market Research, 47, 6, 615-639.

Eggers, F./Kraus, S./Hughes, M./Laraway, S./Snycerski, S. (2013): Implications of Customer and Entrepreneurial Orientations for SME Growth, in: Management Decision, 51, 6 (in press).

Eisenmann, T.R. (2006): Internet companies' growth strategies: Determinants of investment intensity and long-term performance, in: Strategic Management Journal, 27, 12, 1183 1204

Entrialgo, M./Fernández, E./Vázquez, C.J. (2000): Linking entrepreneurship and strategic management: evidence from Spanish SMEs, in: Technovation, 20, 8, 427-436.

European Commission (2011a): SBA Factsheet 2010/11 Austria. http://ec.europa.eu/enterprise/policies/sme/facts-figures-analysis/performancereview/files/countries-sheets/2010-2011/austria_en.pdf (accessed October 2012).

European Commission (2011b): SBA Factsheet 2010/11 Hungary. http://ec.europa.eu/enterprise/policies/sme/facts-figures-analysis/performancereview/files/countries-sheets/2010-2011/hungary_en.pdf (accessed October 2012).

Fornell, C./Larcker, D.F. (1981): Evaluating Structural Equation Models with Unobserved Variables and Measurement Error, in: Journal of Marketing Research, 18, 1, 39-50.

Garnsey, E. (1998): A theory of the early growth of the firm, in: Industrial and Corporate Change, 7, 3, 523-556.

Garnsey, E./Heffernan, P. (2005): Growth setbacks in new firms, in: Futures, 37, 7, 675-697.

Global Entrepreneurship Research Association (2012): Global Entrepreneurship Monitor. Key Indicators. http://www.gemconsortium.org/Data (accessed October 2012).

Gupta, V./Hanges, P.J./Dorfman, P. (2002): Cultural clusters: methodology and findings, in: Journal of World Business, 37, 1, 11-15.

Hair, J.F./Black, W.C./Babin, B.J./Anderson, R.E. (2010): Multivariate Data Analysis. Upper Saddle River, NJ: Pearson Prentice Hall.

Hamel, G./Prahalad, C.K. (1994): Competing for the future. Boston: Harvard Business School Press. 
Harms, R./Reschke, C.H./Kraus, S./Fink, M. (2010): Antecedents to Innovation and Growth: Analyzing the Impact of Entrepreneurial Orientation and Goal-oriented Management, in: International Journal of Technology Management, 52, 1/2, 135-152.

Henderson, J./Weiler, S. (2010): Entrepreneurs and Job Growth: Probing the Boundaries of Time and Space, in: Economic Development Quarterly 24, 1, 23-32.

Hitt, M.A./Ireland, R.D./Camp, S.M./Sexton, D.L. (2002): Strategic entrepreneurship: Integrating entrepreneurial and strategic management perspectives, in: Hitt, M.A./Ireland, R.D./Camp, S.M./Sexton, D.L. (eds.): Strategic Entrepreneurship: Creating a new mindset, Oxford: Blackwell, 1-13.

Hofstede, G. (2006): What did GLOBE really measure? Researchers' minds versus respondents' minds, in: Journal of International Business Studies, 37, 6, 882-896.

Hofstede, G. (2012): National Cultural Dimensions. http://geert-hofstede.com/nationalculture.html (accessed April 2012).

Hofstede, G./Hofstede, G.J./Minkov, M. (2010): Cultures and Organizations - Software of the Mind: Intercultural Cooperation and Its Importance for Survival. New York: McGrawHill.

House, R.J./Hanges, P.J./Javidan, M./Dorfman, P.W./Gupta, V. (2004): Culture, leadership and organization: The GLOBE study of 62 societies. Thousand Oaks, CA: Sage.

International Monetary Fund (2012): World Economic Outlook Database. https://http://www.imf.org/external/pubs/ft/weo/2012/01/weodata/index.aspx (accessed October 2012).

Javidan, M./House, R.J./Dorfman, P.W./Hanges, P.J./Sully de Luque, M. (2006): Conceptualizing and measuring cultures and their consequences: a comparative review of GLOBE's and Hofstede's approaches, in: Journal of International Business Studies, $37,6,897-914$.

Kallay, L./Kovacs, E.K./Kohegyi, K./Maszlag, L. (2008): State of Small and Medium-Sized Business in Hungary. Annual Report. Budapest: Ministry of National Development and Economy Republic of Hungary.

Katila, R./Shane, S. (2005): When does lack of resources make new firms innovative?, in: Academy of Management Journal, 48, 5, 814-829.

Keskin, H. (2006): Market orientation, learning orientation, and innovation capabilities in SMEs: An extended model, in: European Journal of Innovation Management, 9, 4, 396-417.

Kline, R.B. (1998): Principles and Practice of Structural Equation Modeling. New York: The Guilford Press.

Knight, F.H. (1921): Risk, uncertainty and profit. Chicago, IL: University of Chicago Press.

Kraus, S. (2011): The role of entrepreneurial orientation in service firms: empirical evidence from Austria, in: Service Industries Journal (in press; DOI:10.1080/02642069.2011.622373).

Kraus, S./Rigtering, C./Hughes, M./Hosman, V. (2012): Entrepreneurial orientation and the business performance of SMEs: a quantitative study from the Netherlands, in: Review of Managerial Science, 6, 2, 161-182. 
Landström, H. (2009): Pioneers in entrepreneurship and small business research. New York: Springer.

Levratto, N. (1996): Small firms finance in France, in: Small Business Economics, 8, 4, 279295.

Low, M.B./MacMillan, I.C. (1988): Entrepreneurship: Past research and future challenges, in: Journal of Management, 14, 2, 139-161.

Lumpkin, G.T./Dess, G.G. (1996): Clarifying the entrepreneurial orientation construct and linking it to performance, in: Academy of Management Review, 21, 1, 135-172.

Lumpkin, G.T./Dess, G.G. (2001): Linking two dimensions of entrepreneurial orientation to firm performance: The moderating role of environment and industry life cycle, in: Journal of Business Venturing, 16, 5, 429-451.

Macedo, I.M./Pinho, J.C. (2006): The relationship between resource dependence and market orientation - The specific case of non-profit organisations, in: European Journal of Marketing, 40, 5/6, 533-553.

Mako, C./Kuczi, T. (2003): Historical Background and Present Development of Small Business in Hungary: Strong Presence in the Production and Weak Role in the Innovation, in: Ishikawa, A. (ed.) Small and Medium-sized Enterprises in Central Europe: An Overview, Tokyo: Sasakawa Peace Foundation, 60-84.

Matsuno, K./Mentzer, J.T./Rentz, J.O. (2005): A conceptual and empirical comparison of three market orientation scales, in: Journal of Business Research, 58, 1, 1-8.

Miller, D. (1983): The correlates of entrepreneurship in three types of firms, in: Management Science, 29, 7, 770-791.

Miller, D./Friesen, P.H. (1983): Innovation in conservative and entrepreneurial firms: Two models of strategic momentum, in: Strategic Management Journal, 3, 1, 1-25.

Morris, M.H./Kuratko, D.F./Covin, J.G. (2008): Corporate Entrepreneurship \& Innovation. Mason, $\mathrm{OH}, \mathrm{USA}$ : Thomson Higher Education.

Narver, J.C./Slater, S.F. (1990): The Effect of a Market Orientation on Business Profitability, in: Journal of Marketing, 54, 4, 20-35.

Narver, J.C./Slater, S.F./MacLachlan, D.L. (2004): Responsive and proactive market orientation and new-product success, in: Journal of Product Innovation Management, $21,5,334-347$.

Parker, S. (2004): The Economics of Self-Employment and Entrepreneurship. Cambridge: Cambridge University Press.

Penrose, E.T. (1959): The theory of the growth of the firm. New York: John Wiley.

Porter, M.E. (1985): Competitive advantage: creating and sustaining superior performance. New York: The Free Press.

Ricketts, M. (2006): Theories of Entrepreneurship: Historical development and critical assessment, in: M., C./Yeung, B./Basu, A./Wadeson, N. (eds.): The Oxford Handbook of Entrepreneurship, Oxford: Oxford University Press, 33-58.

Roman, E. (2003): Austria-Hungary and the Successor States: A Reference Guide from the Renaissance to the Present. New York: Fast On File. 
Sax, L.J./Gilmartin, S.K./Bryant, A.N. (2003): Assessing response rates and nonresponse bias in web and paper surveys, in: Research in Higher Education, 44, 4, 409-432.

Schumpeter, J.A. (1942): Capitalism, Socialism and Democracy. New York: Harper \& Brothers.

Sciascia, S./Naldi, L./Hunter, E. (2006): Market orientation as determinant of entrepreneurship: An empirical investigation on SMEs, in: International Entrepreneurship and Management Journal, 2, 1, 21-38.

Sexton, D.L./Kasarda, J.D. (1992): State of the Art of Entrepreneurship. PWS-Kent: Boston, MA.

Shepherd, D.A./Wiklund, J. (2005): Entrepreneurial Small Business: A resource-based perspective. Northampton, MA: Edward Elgar.

Shi, X./Wang, J. (2011): Interpreting Hofstede Model and GLOBE Model: Which Way to Go for Cross-Cultural Research?, in: International Journal of Business and Management, 6, 5, 93-99.

Slater, S.F./Narver, J.C. (1998): Customer-led and market-oriented - let's not confuse the two, in: Strategic Management Journal, 19, 10, 1001-1006.

Szabo, E./Brodbeck, F.C./Den Hartog, D.N./Reber, G./Weibler, J./Wunderer, R. (2002): The Germanic Europe cluster: where employees have a vioce, in: Journal of World Business, 37, 1, 55-68.

Valliere, D. (2006): Consequences of growth: Shaping entrepreneurial attitudes, in: International Journal of Entrepreneurship and Innovation, 7, 3, 141-148.

Wiklund, J. (1999): The sustainability of the entrepreneurial orientation-performance relationship, in: Entrepreneurship Theory and Practice, 24, 1, 37-48.

Wiklund, J./Shepherd, D.A. (2005): Entrepreneurial Orientation and Small Business Performance: A Configuration Approach, in: Journal of Business Venturing, 20, 1, 7191.

Wright, K.B. (2005): Researching Internet-Based Populations: Advantages and Disadvantages of Online Survey Research, Online Questionnaire Authoring Software Packages, and Web Survey Services, in: Journal of Computer-Mediated Communication, 10, 3.

Zahra, S.A./Bogner, W.C. (2000): Technology Strategy and Software New Ventures' Performance: Exploring the Moderating Effect of the Competitive Environment, in: Journal of Business Venturing, 15, 2, 135-173.

Zahra, S.A./Garvis, D.M. (2000): International Corporate Entrepreneurship And Firm Performance: The Moderating Effect Of International Environmental Hostility, in: Journal of Business Venturing, 15, 5-6, 469-493. 